\title{
Analisis Perbandingan Metode Simple Additive Weighting dan Profile Matching dalam Sistem Pendukung Keputusan
}

\author{
Heri Abijono ${ }^{1}$, Kusrini ${ }^{2}$ \\ ${ }^{1,2}$ Magister Teknik Informatika, Universitas AMIKOM Yogyakarta \\ E-mail: $\underline{* 1 \text { ahabijono@gmail.com }}, \underline{{ }^{2} \text { kusrini@amikom.ac.id }}$
}

\begin{abstract}
Abstrak-Peneliti telah menerapkan sistem pendukung keputusan berupa suatu aplikasi untuk mendistribusikan dana Bantuan Siswa Miskin (BSM) di tahun 2015 dengan menggunakan metode Simple Additive Weighting. Peneliti kemudian mengembangkan sistem ini di tahun 2017 dengan menambahkan ketentuan kepemilikan Kartu Perlindungan Sosial ataupun Surat Keterangan Rumah Tangga Miskin untuk mempertimbangkan prioritas pemberian dana bantuan itu, selain mempertimbangkan empat macam kriteria yang telah ada pada sistem sebelumnya. Penelitian kali ini ditujukan untuk membandingkan algoritma dari dua metode, Simple Additive Weighting dan Profile Matching, untuk menentukan metode mana yang cocok dipakai dalam pendistribusian dana BSM. Peneliti membuat analisis berupa perhitungan-perhitungan sesuai algoritma dari dua buah metode yang diperbandingkan dengan menunjukkan cara kerja proses dari tiap-tiap metode yang diperbandingkan. Keluaran sistem adalah berupa informasi perankingan prioritas siswa untuk memperoleh dana BSM.
\end{abstract}

Kata Kunci-Pendukung, keputusan, distribusi, bantuan, prioritas, membandingkan

\begin{abstract}
Researcher have implemented a decision support system in the form of an application to distribute Poor Student Assistance (BSM) funds in 2015 by using Simple Additive Weighting method. The researcher then developed this system in 2017 by adding the terms of ownership of the Social Protection Card or the Poor Household Certificate to consider the priority of granting the grant, in addition to considering four different criteria that existed in the previous system. This research is aimed to compare the algorithm of two methods, Simple Additive Weighting and Profile Matching, to determine which method is suitable to be used in distributing BSM funds. The researcher made an analysis of calculations according to the algorithm of the two comparable methods by showing how the process works of each method is compared. The output of the system is in the form of ranking priority information of students to obtain BSM funds.
\end{abstract}

Keywords - Supporter, decision, distribution, assistance, priority, comparing

\section{PENDAHULUAN}

Pemerintah mengingatkan kepada seluruh siswa yang berhak mendapatkan Bantuan Siswa Miskin (BSM) untuk segera melakukan pendataan diri di sekolah/madrasah masing-masing. Proses pendataan tahap II (tahap terakhir) telah berakhir pada 13 September 2013. Untuk mendaftarkan diri sebagai calon penerima BSM diperlukan Kartu Perlindungan Sosial (KPS) ataupun Kartu Calon Penerima BSM. Namun KPS ataupun Kartu Calon Penerima BSM dapat digantikan dengan Surat Keterangan Rumah Tangga Miskin (SKRTM) yang dikeluarkan oleh Kantor Desa / Kelurahan tempat domisili orangtua/wali siswa [1]. Kemiskinan merupakan ketidakmampuan dari sisi ekonomi untuk memenuhi kebutuhan pokok minimum (basic need approach) baik pangan maupun non pangan semisal sandang, pangan, kesehatan, erumahan, dan pendidikan yang diperlukan untuk bisa hidup dan bekerja. Kemiskinan dipandang sebagai ketidakmampuan diukur dari sisi pengeluaran, sehingga penduduk miskin adalah penduduk yang tidak mampu memenuhi kebutuhan pokok dengan rata-rata pengeluaran perkapita di bawah garis kemiskinan (GK) [2]. Kartu Perlindungan Sosial (KPS) adalah kartu yang diterbitkan oleh Pemerintah sebagai penanda rumah tangga miskin. KPS 
dirancang sebagai penanda universal bagi rumah tangga sasaran (RTS) untuk mengakses program perlindungan. memuat informasi: Nama Kepala Rumah Tangga, Nama Pasangan Kepala Rumah Tangga, Nama Anggota Rumah Tangga Lain, Alamat Rumah Tangga, Nomor Kartu Keluarga, dilengkapi dengan kode batang (barcode) beserta nomor identitas KPS yang unik. Kartu Perlindungan Sosial berguna untuk mendapatkan program subsidi beras (RASKIN), Bantuan Siswa Miskin (BSM), Bantuan Langsung Tunai (BLT), dan bantuan-bantuan yang lain [3].

Tahun 2015 peneliti telah membuat suatu aplikasi pengambilan keputusan untuk menentukan ranking prioritas siswa dalam memperoleh dana BSM pada SMP Negeri 2 Kecamatan Wates Kabupaten Kediri dengan menerapkan algoritma dari metode Simple Additive Weighting, namun sistem ini tidak membedakan prioritas siswa dengan orangtua/wali apakah memiliki KPS/SKM ataukah tidak. Di awal tahun 2017 peneliti mengembangkan program itu yan kemudian diterapkan pada SMP Negeri 6 Kabupaten Nganjuk dengan menambahkan aturan bahwa prioritas diutamakan bagi para siswa dengan orangtua/wali memiliki KPS/SKM. Prioritas kedua pendistribusian dana BSM ini diberikan kepada para siswa dengan orangtua/walinya mengisi angket rekomendasi pemberian dana BSM walaupun mereka tidak memiliki KPS/SKM, dan prioritas terakhir dana BSM disalurkan kepada para orangtua/wali yang tidak mengisi angket rekomendasi itu ataupun tidak mengembalikan angket itu kepada panitia pendistribusian dana BSM. Pada angket itu terdapat pertanyaan-pertanyaan dan setiap pertanyaan membutuhkan jawaban dari orangtua/wali siswa. Macam-macam pertanyaan ini merupakan kriteria-kriteria yang akan diuji dan pilihan-pilihan jawaban pada setiap pertanyaan memiliki nilai bobot yang mempengaruhi hasil dari proses perhitungan untuk menentukan nilai persentase prioritas/peluang siswa dalam menerima dana BSM. Hasil dari keluaran program dapat bersifat objektif dalam penentuan ranking prioritas siswa untuk memperoleh dana BSM.

Sistem pendukung keputusan perlu dibuat untuk menjaga keakuratan hasil pemrosesan data. Sistem pendukung keputusan adalah suatu sistem berbasis komputer interaktif yang membantu para pengambil keputusan untuk menggunakan data dan berbagai model untuk memecahkan masalah yang tidak terstruktur [4]. Terdapat pula pendapat lain yang mendefinisikan bahwa, sistem pendukung keputusan atau yang disebut dengan DSS (Decision Support System) adalah sistem berbasis komputer yang ditujukan untuk membantu pengambil keputusan dengan memanfaatkan data dan model untuk mengidentifikasi, memecahkan masalah dan membuat keputusan [5]. Secara umum sistem pendukung keputusan dibangun oleh tiga komponen besar yaitu Database Management, Model Base, dan Software System/User Interface. Hubungan komponen SPK ditunjukkan melalui Gambar 1.

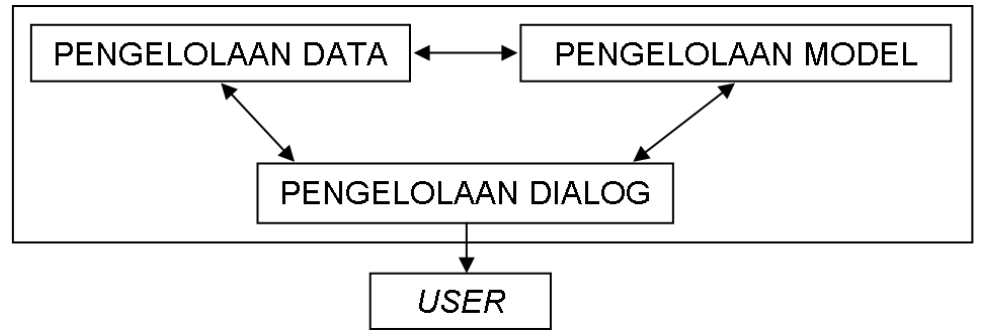

Gambar 1. Komponen Sistem Pendukung Keputusan [6]

Komponen-komponen sistem pendukung keputusan pada gambar 1 dapat dijelaskan sebagai berikut:

a. Pengelolaan Data / Database Management

Pengelolaan ini merupakan subsistem data yang terorganisasi dalam suatu basis data. Data yang merupakan suatu sistem pendukung keputusan dapat berasal dari luar maupun dalam lingkungan. Untuk keperluan sistem pendukung keputusan diperlukan data yang relevan dengan permasalahan yang hendak dipecahkan melalui simulasi [6]. 
b. Pengelolaan Model / Model Base

Pengelolaan ini merupakan suatu model yang merepresentasikan permasalahan ke dalam format kuantitatif (model matematika sebagai contohnya) sebagai dasar simulasi atau pengambilan keputusan, termasuk didalamnya tujuan dari permasalahan (obyektif), komponen-komponen terkait, batasan-batasan yang ada (constraints), dan hal-hal terkait lainnya. Model Base memungkinkan pengambil keputusan menganalisa secara utuh dengan mengembangkan dan membandingkan solusi alternatif [6].

c. Pengelolaan Dialog / User Interface

Pengelolaan ini terkadang disebut sebagai subsistem dialog, merupakan penggabungan antara dua komponen sebelumnya yaitu Database Management dan Model Base yang disatukan dalam komponen ketiga (user interface), setelah sebelumnya dipresentasikan dalam bentuk model yang dimengerti komputer. User interface menampilkan keluaran sistem bagi pemakai dan menerima masukan dari pemakai ke dalam sistem pendukung keputusan [6].

\section{METODE PENELITIAN}

Pada bagian ini peneliti menjelaskan mengenai metodologi penelitian, jenis penelitian, sifat penelitian, pendekatan penelitian, metode pengumpulan data, dan metode analisis data.

\subsection{Metodologi Penelitian}

Langkah-langkah penelitian yang dilakukan peneliti mengikuti alur seperti yang ditunjukkan pada Gambar 2 di bawah ini.

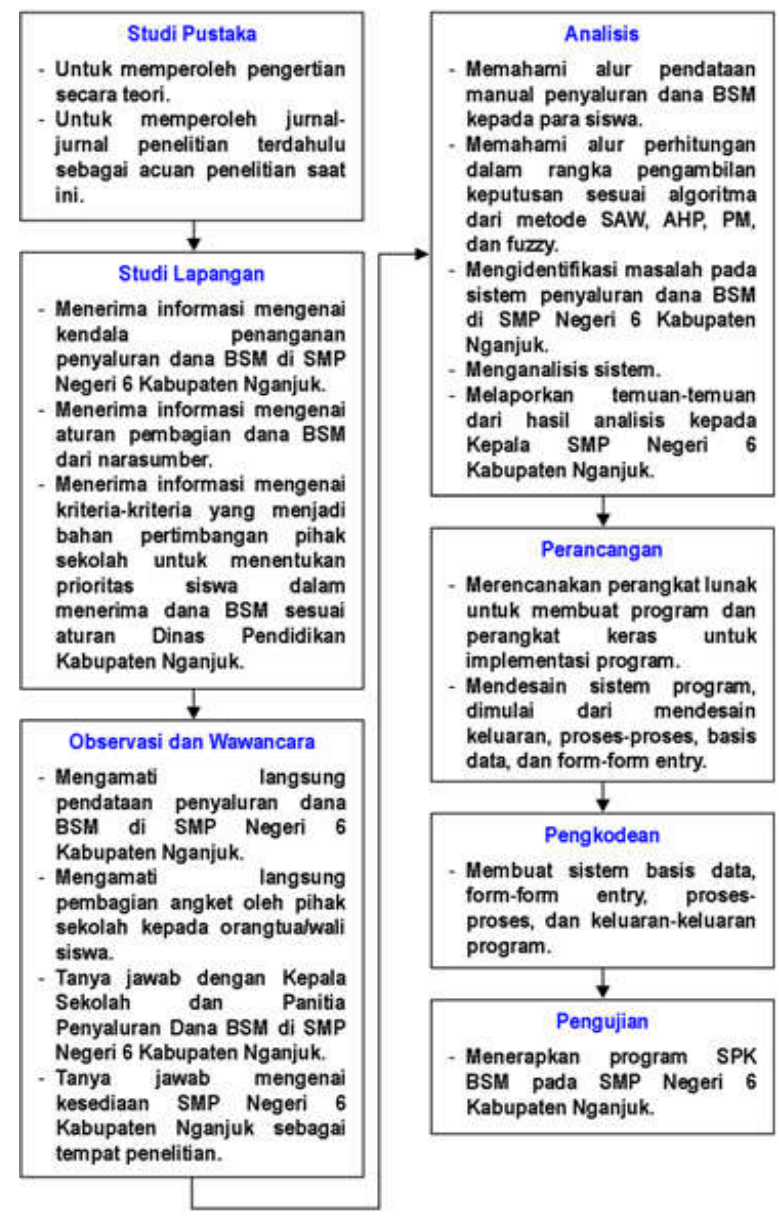

Gambar 2. Metodologi Penelitian 


\subsection{Jenis, Sifat, dan Pendekatan Penelitian}

Jenis penelitian yang dilakukan adalah tindakan, karena peneliti mengumpulkan angket yang telah dikembalikan oleh orangtua/wali siswa dan peneliti memberi nilai bobot untuk tiap-tiap jawaban pada angket. Nilai bobot baku untuk setiap kriteria telah ditetapkan oleh pihak sekolah.

Sifat penelitian adalah deskriptif, yaitu mendeskripsikan kegiatan penelitian dari tahap awal, melakukan analisis perhitungan, sampai membuat suatu kesimpulan berdasarkan kejadian nyata pada kegiatan penyaluran dana BSM kepada para siswa oleh Panitia BSM di SMP Negeri 6 Kabupaten Nganjuk.

Pendekatan penelitian ini adalah bersifat kualitatif, yaitu memahami cara kerja algoritma tiap-tiap metode dalam sistem pengambilan keputusan yang akan dibandingkan, kemudian algoritma itu dipakai untuk pemrosesan pengambilan keputusan sampai menghasilkan keluaran berupa hasil perankingan prioritas siswa dalam menerima dana BSM.

\subsection{Metode Pengumpulan Data}

Peneliti melakukan pengumpulan data pada penelitian ini dengan cara:

a. Peneliti melakukan observasi dan wawancara dengan anggota tim Panitia Penyaluran Dana BSM. Dari kegiatan ini peneliti dapat mengetahui aturan-aturan mengenai penyaluran dana BSM kepada para siswa dan kriteria-kriteria yang menjadi bahan pertimbangan panitia dalam menyalurkan dana BSM.

Aturan-aturan mengenai penyaluran dana BSM kepada para siswa meliputi:

1) Dana BSM dibagikan secara merata kepada seluruh siswa.

2) Para orangtua/wali siswa yang memiliki KPS ataupun dapat menunjukkan SKM mendapat prioritas pertama untuk menerima dana BSM.

3) Angket rekomendasi penerimaan dana BSM dari sekolah dibagikan khusus kepada para orangtua/wali siswa yang tidak memiliki KPS/SKM.

4) Orangtua/wali siswa mengisi angket itu dan mengembalikannya kepada Panitia Penyaluran Dana BSM, untuk keperluan pemrosesan penyaluran dana BSM.

5) Orangtua/wali siswa yang tidak mengisi angket itu ataupun tidak mengembalikan angket itu kepada Panitia Penyaluran Dana BSM, mereka tetap dapat menerima dana BSM pada urutan terakhir setelah dana BSM dibagikan kepada grup orangtua/wali siswa yang memiliki KPS/SKM dan grup orangtua/wali siswa yang mengembalikan angket itu kepada Panitia Penyaluran Dana BSM.

Tabel 1 di bawah ini mencatat kriteria-kriteria penyaluran dana BSM yang ditetapkan oleh Panitia Penyaluran Dana BSM SMP Negeri 6 Kabupaten Nganjuk.

Tabel 1. Kriteria dan Bobot yang Ditetapkan

\begin{tabular}{llr}
\hline \hline Nama Kriteria & \multicolumn{1}{c}{ Keterangan } & \multicolumn{1}{c}{ Bobot } \\
\hline K1 & Penghasilan orangtua/wali & $35 \%$ \\
K2 & Keadaan bangunan rumah orangtua/wali & $35 \%$ \\
K3 & Jumlah saudara siswa & $15 \%$ \\
K4 & Jumlah anak yang masih menjadi tanggungan orangtua & $15 \%$
\end{tabular}

Tabel 2 di bawah ini mencatat pilihan-pilihan untuk kriteria K1 dan nilai untuk masing-masing pilihan pada kriteria $\mathrm{K} 1$.

Tabel 2. Nilai yang Ditetapkan untuk Kriteria K1

\begin{tabular}{lr}
\hline \hline \multicolumn{1}{c}{ Batasan Penghasilan Orangtua/Wali Siswa Per Bulan } & Nilai \\
\hline Kurang dari Rp 500.000,00 & 10 \\
Antara Rp 500.000,00 sampai Rp 1.000.000,00 & 6 \\
Antara Rp 1.000.000,00 sampai Rp 2.000.000,00 & 4 \\
Lebih dari Rp 2.000.000,00 & 2
\end{tabular}

Tabel 3 di bawah ini mencatat pilihan-pilihan untuk kriteria K2 dan nilai untuk masing-masing pilihan pada kriteria $\mathrm{K} 2$. 
Tabel 3. Nilai yang Ditetapkan untuk Kriteria K2

\begin{tabular}{lr}
\hline \hline \multicolumn{1}{c}{ Keadaan Bangunan Rumah Orangtua/Wali Siswa } & Nilai \\
\hline Rumah sangat sederhana (RSS) & 10 \\
Rumah sederhana (RSd) & 8 \\
Rumah standar (RSt) & 4 \\
Rumah mewah (RM) & 2
\end{tabular}

Panitia Penyaluran Dana BSM SMP Negeri 6 Kabupaten Nganjuk menetapkan bahwa untuk kriteria K3 dan kriteria K4 adalah berupa pertanyaan yang meminta jawaban dari orangtua/wali siswa dengan cara diisi nilai angka sesuai dengan jumlah saudara siswa dan jumlah anak yang masih menjadi tanggungan orangtua siswa, seperti yang ditulis pada Gambar 3.

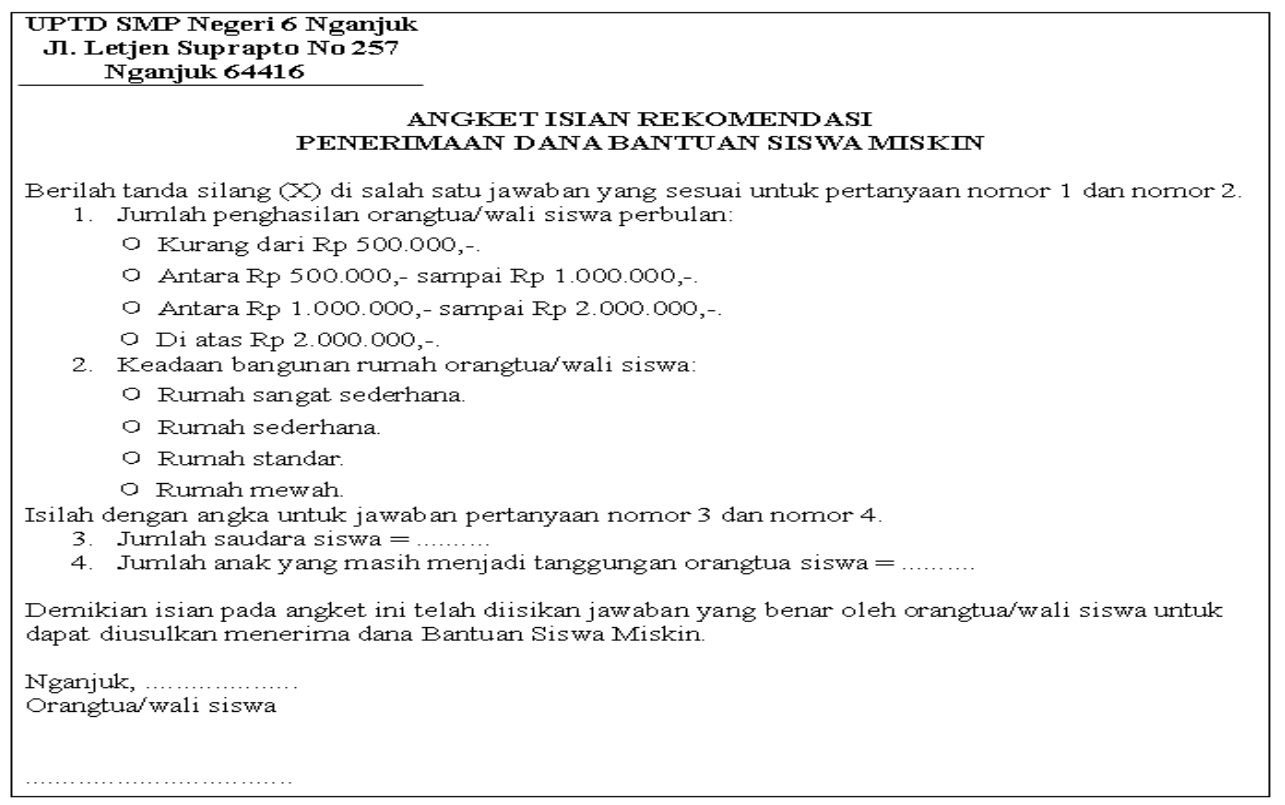

Gambar 3. Angket Isian Rekomendasi Dana BSM

b. Wawancara lain yang telah dilakukan oleh peneliti dengan Tim Panitia Penyaluran Dana BSM adalah mengenai pemrosesan data dari perolehan jawaban pada angket di Gambar 2 sampai menghasilkan perankingan nama para siswa yang berhak mendapatkan dana BSM. Dari kegiatan ini peneliti dapat melihat worksheet Microsoft Excell yang dipakai oleh panitia tersebut adalah dengan cara menjumlahkan langsung nilai-nilai pada tiap-tiap jawaban dalam angket itu untuk mendapatkan nilai prioritas siswa dalam menerima dana BSM.

c. Dari hasil observasi dan wawancara ini peneliti memahami bahwa kriteria-kriteria yang ditulis pada Tabel 1 dapat dijadikan sebagai kriteria-kriteria yang akan diuji oleh metode-metode sistem pendukung keputusan yang dibahas dalam penelitian ini. Acuan nilai bobot untuk Kriteria 1 dapat peneliti ambil dari data pada Tabel 2 dan acuan nilai bobot untuk Kriteria 2 dapat peneliti ambil dari data pada Tabel 3. Sehingga nanti alur perhitungan pengambilan keputusan melalui metode-metode yang dibahas dalam penelitian ini mengacu kepada data dari Tabel 1 sampai Tabel 3 khusus untuk perankingan prioritas siswa penerima BSM dari grup orangtua/wali yang mengisi dan mengembalikan angket kepada Panitia Penyaluran Dana BSM di sekolah ini. 


\subsection{Metode Analisis Data}

Langkah-langkah dalam analisis data yang dilakukan oleh peneliti meliputi:

a. Mengklasifikasi Data

Klasifilasi data dibuat sesuai kriteria-kriteria yang akan diuji oleh metode-metode sistem pendukung keputusan sesuai keperluan penyaluran dana BSM. Macam-macam kriteria ini telah ditulis pada Tabel 1. Macam-macam kriteria ini kemudian menjadi pertanyaan-pertanyaan yang ditulis pada angket rekomendasi penyaluran dana BSM seperti yang telah ditunjukkan pada Gambar 2.

b. Menganalisis Data

Analisis data dilakukan dalam proses perhitungan sesuai metode sistem pendukung keputusan yang dimaksudkan untuk mencari kesimpulan/solusi akhir, yaitu berupa ranking prioritas siswa dalam menerima dana BSM khusus mereka yang tidak memiliki KPS/SKM.

c. Memaknai Data

Memaknai data bertujuan untuk menghindari kesalahan dalam proses perhitungan, sebab setiap kriteria memiliki nilai bobot yang telah ditentukan (untuk kriteria K1 dan kriteria K2) maupun nilai bobot sesuai perolehan jawaban pada angket yang telah dijawab oleh orangtua/wali siswa (untuk kriteria K3 dan kriteria K4).

d. Menarik Kesimpulan

Penarikan kesimpulan dilakukan atas hasil akhir (solusi) dari setiap metode sistem pendukung keputusan yang dipilih, maupun penarikan kesimpulan mengenai penentuan metode mana yang terbaik khusus untuk kasus penyaluran dana BSM ini.

\section{HASIL DAN PEMBAHASAN}

Perbandingan dua metode pada penelitian ini ditujukan untuk mengetahui tingkat keberhasilan penerapan metode pada [7] suatu sistem pendukung keputusan. Dengan menggunakan data dan kriteria yang sama [7], sistem ini menyelesaikan permasalahan pendistribusian dana BSM.

Tabel 4 di bawah ini berisi data jawaban angket dari para siswa yang akan dicari peringkat prioritas/peluang untuk memperoleh dana BSM. Tabel 4 ini merupakan tabel penilaian dari tiap-tiap alternatif (siswa) pada setiap kriteria sesuai pertanyaan angket.

Tabel 4. Data Calon Penerima Dana BSM

\begin{tabular}{|c|c|c|c|c|c|}
\hline \multirow[b]{2}{*}{ Nama Siswa } & \multirow[b]{2}{*}{ KPS/SKM } & \multicolumn{4}{|c|}{ Kriteria } \\
\hline & & $\mathrm{K} 1$ & $\mathrm{~K} 2$ & $\mathrm{~K} 3$ & K4 \\
\hline Ninik Setyorini & $\mathrm{Y}$ & 10 & 8 & 3 & 2 \\
\hline Indah Astutik & $\mathrm{Y}$ & 6 & 10 & 2 & 1 \\
\hline Bambang Suhartoyo & $\mathrm{T}$ & 4 & 4 & 1 & 0 \\
\hline Tomy Setyawan & $\mathrm{Y}$ & 2 & 4 & 2 & 1 \\
\hline Setiawan & $\mathrm{Y}$ & 6 & 10 & 5 & 3 \\
\hline Melati Anggraini & $\mathrm{T}$ & 4 & 4 & 0 & 0 \\
\hline Agustin Neni & $\mathrm{T}$ & 2 & 4 & 3 & 3 \\
\hline Pongki Pramudia & $\mathrm{T}$ & 10 & 8 & 2 & 2 \\
\hline Moh. Saiful & $\mathrm{T}$ & 4 & 4 & 1 & 1 \\
\hline Andik Arafik & $\mathrm{T}$ & 2 & 4 & 2 & 2 \\
\hline
\end{tabular}

Kolom KPS/SKM menunjukkan tentang kepemilikan KPS/SKM, nilai "Y" untuk para siswa yang memiliki KPS/SKM, dan nilai "T" untuk para siswa yang tidak memiliki KPS/SKM.

Untuk siswa yang memiliki KPS/SKM mendapat prioritas pertama dalam menerima dana BSM, sehingga pencarian solusi melalui penyelesaian dengan metode Simple Additive Weighting dan Profile Matching di bawah ini dikhususkan untuk perankingan urutan siswa yang tidak memiliki KPS/SKM yaitu Bambang Suhartoyo, Melati Anggraini, Agustin Neni, Pongki Pramudia, Moh. Saiful, dan Andik Arafik.

\subsection{Analisis Pencarian Solusi dengan Metode Metode Simple Additive Weighting}


Cara kerja metode Simple Additive Weighting adalah dengan mencari penjumlahan terbobot dari rating kinerja pada setiap alternatif pada semua atribut, metode ini juga membutuhkan proses normalisasi matriks keputusan $(\mathrm{X})$ ke suatu skala yang dapat diperbandingkan dengan semua rating alternatif yang ada. Proses normalisasi didapat untuk tiap kolom kriteria dengan membaginya dengan nilai kolom kriteria yang tertinggi dalam kolom matriks tersebut [8].

Rumus untuk melakukan normalisasi di metode Simple Additive Weighting adalah:

$$
\mathrm{r}_{\mathrm{ij}}=\left\{\begin{array}{l}
\mathrm{X}_{\mathrm{ij}} / \operatorname{Max}_{\mathbf{i}} \mathrm{X}_{\mathrm{ij}} ; \mathrm{jika} \mathrm{j} \text { adalah atribut benefit } \\
\operatorname{Min}_{\mathrm{i}} \mathrm{X}_{\mathrm{ij}} / \mathrm{x}_{\mathrm{ij}} ; \mathrm{jika} \mathrm{j} \text { adalah atribut cost.... }
\end{array}\right.
$$

Dengan $\mathrm{r}_{\mathrm{ij}}$ adalah rating kinerja ternormalisasi dari alternative $\mathrm{A}_{\mathbf{i}}$ pada atribut $\mathrm{C}_{\mathbf{j}}$; di mana $\mathrm{i}=1,2$, $\ldots, \mathrm{m} ;$ dan $\mathrm{j}=1,2, \ldots, \mathrm{n}[8]$.

$$
r_{i j}=\sum_{j=1}^{n} W_{i} r_{i j}
$$

Dimana nilai $V_{\mathbf{i}}$ yang lebih besar mengindikasikan bahwa alternatif $A_{\mathbf{i}}$ lebih terpilih [9].

Penyelesaian permasalahan pendistribusian dana BSM dengan metode Simple Additive Weighting terdiri dari langkah-langkah di bawah ini:

a. Mencari nilai normalisasi setiap alternatif untuk setiap kriteria [9], yaitu untuk kriteria K1 sampai kriteria K4 pada Tabel 4

Nilai n Bambang untuk K1:

$\mathrm{n}_{\text {Bambang }}=4 / \max \{10 ; 6 ; 4 ; 2 ; 6 ; 4 ; 2 ; 10 ; 4 ; 2\}$

$$
=4 / 10=0.4 \text {. }
$$

Nilai n Bambang untuk K2:

$\mathrm{n}_{\text {Bambang }}=4 / \max \{8 ; 10 ; 4 ; 4 ; 10 ; 4 ; 4 ; 8 ; 4 ; 4\}$

$$
=4 / 10=0.4 \text {. }
$$

Nilai n Bambang untuk K3:

$\mathrm{n}_{\text {Bambang }}=1 / \max \{3 ; 2 ; 1 ; 2 ; 5 ; 0 ; 3 ; 2 ; 1 ; 2\}$

$$
=1 / 5=0.2 \text {. }
$$

Nilai n Bambang untuk K4:

$\mathrm{n}_{\text {Bambang }}=0 / \max \{2 ; 1 ; 0 ; 1 ; 3 ; 0 ; 3 ; 2 ; 1 ; 2\}$

$$
=0 / 3=0 \text {. }
$$

Dengan cara yang sama seperti perhitungan nilai n untuk Bambang kemudian dapat dicari nilai $\mathrm{n}$ untuk setiap alternatif yang lain yang tidak memiliki KPS/SKM seperti perincian perhitungan di bawah ini:

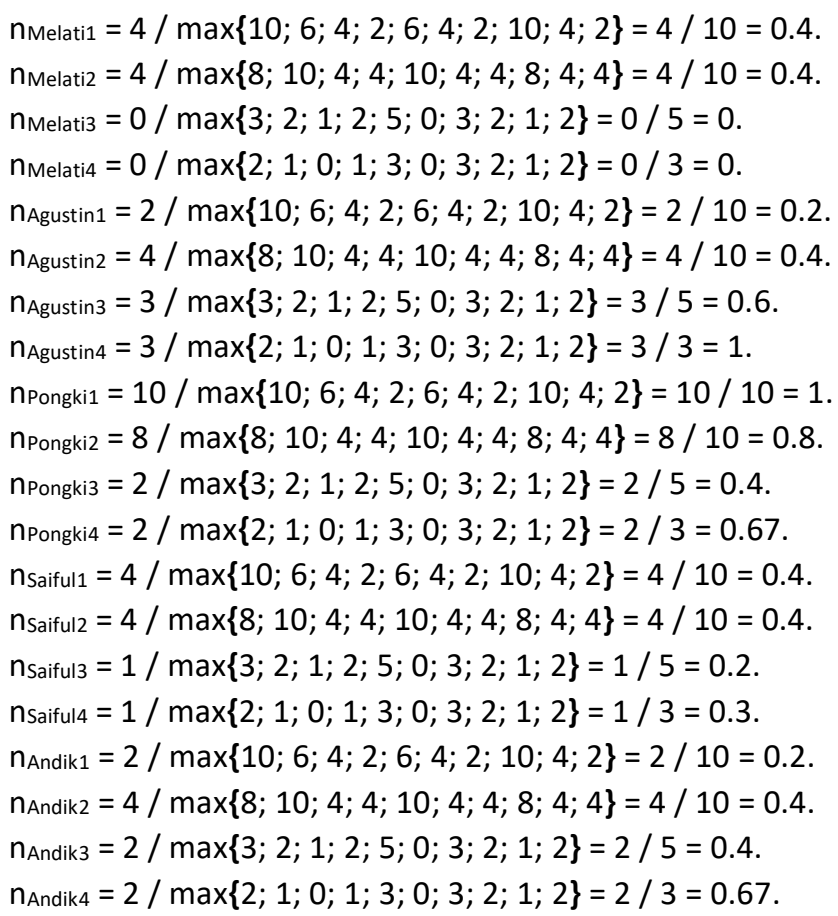


b. Menyusun matriks $\mathrm{R}$

Hasil dari proses normalisasi pada langkah (a) di atas kemudian dapat dibentuk suatu matriks R sebagai berikut:

$$
\mathrm{R}=\begin{array}{llll|}
0.4 & 0.4 & 0.2 & 0 \\
0.4 & 0.4 & 0 & 0 \\
0.2 & 0.4 & 0.6 & 1 \\
1 & 0.8 & 0.4 & 0.67 \\
0.4 & 0.4 & 0.2 & 0.3 \\
0.2 & 0.4 & 0.4 & 0.67 \\
\hline
\end{array}
$$

c. Menghitung nilai P (priority) untuk tiap alternatif

Nilai-nilai pada tiap-tiap baris untuk tiap-tiap kolom pada matriks $\mathrm{R}$ di langkah (b) kemudian dikalikan dengan nilai bobot yang telah ditetapkan untuk tiap-tiap kriteria di Tabel 1 sehingga diperoleh perhitungan di bawah ini:

$$
\begin{aligned}
& P_{\text {Bambang }}=0.35 * 0.4+0.35 * 0.4+0.15 * 0.2+0.15 * 0=0.14+0.14+0.03+0=0.31 \text {. } \\
& P_{\text {Melati }}=0.35 * 0.4+0.35 * 0.4+0.15 * 0+0.15 * 0=0.14+0.14+0+0=0.28 \text {. } \\
& P_{\text {Agustin }}=0.35 * 0.2+0.35 * 0.4+0.15 * 0.6+0.15 * 1=0.7+0.14+0.09+0.15=0.45 \\
& P_{\text {Pongki }}=0.35 * 1+0.35 * 0.8+0.15 * 0.4+0.15 * 0.67 \\
& =0.35+0.28+0.06+0.1005=0.7905 \text {. } \\
& P_{\text {Saiful }}=0.35 * 0.4+0.35 * 0.4+0.15 * 0.2+0.15 * 0.3 \\
& =0.14+0.14+0.03+0.045=0.355 \text {. } \\
& P_{\text {Andik }}=0.35 * 0.2+0.35 * 0.4+0.15 * 0.4+0.15 * 0.67 \\
& =0.07+0.14+0.06+0.1005=0.3705 \text {. }
\end{aligned}
$$

\begin{tabular}{|c|c|c|c|}
\hline Nama Siswa & KPS/SKM & Prioritas & Solusi \\
\hline Ninik Setyorini & $\mathrm{Y}$ & $100 \%$ & Urutan 1 \\
\hline Indah Astutik & $\mathrm{Y}$ & $100 \%$ & Urutan 1 \\
\hline Tomy Setyawan & $\mathrm{Y}$ & $100 \%$ & Urutan 1 \\
\hline Setiawan & $\mathrm{Y}$ & $100 \%$ & Urutan 1 \\
\hline Pongki Pramudia & $\mathrm{T}$ & $79 \%$ & Urutan 2 \\
\hline Agustin Neni & $\mathrm{T}$ & $45 \%$ & Urutan 3 \\
\hline Andik Arafik & $\mathrm{T}$ & $37 \%$ & Urutan 4 \\
\hline Moh. Saiful & $\mathrm{T}$ & $35,5 \%$ & Urutan 5 \\
\hline Bambang Suhartoyo & $\mathrm{T}$ & $31 \%$ & Urutan 6 \\
\hline Melati Anggraini & $\mathrm{T}$ & $28 \%$ & Urutan 7 \\
\hline
\end{tabular}

d. Perankingan

Tabel 5 di bawah ini berisi informasi nilai prioritas dengan urutan descending yang diperoleh dari perhitungan nilai $\mathrm{P}$ pada langkah (c).

Tabel 5. Perankingan Prioritas

\begin{tabular}{ll}
\hline \hline Nilai Priority & \multicolumn{1}{c}{ Nama Siswa } \\
\hline $0.7905=79 \%$ & Pongki Pramudia \\
$0.45=45 \%$ & Agustin Neni \\
$0.3705=37 \%$ & Andik Arafik \\
$0.355=35,5 \%$ & Moh. Saiful \\
$0.31=31 \%$ & Bambang Suhartoyo \\
$0.28=28 \%$ & Melati Anggraini
\end{tabular}

Solusi lengkap dengan metode Simple Additive Weighting dapat disusun menjadi suatu informasi penyaluran dana BSM seperti yang ditulis pada Tabel 6.

Tabel 6. Solusi dari Metode Simple Additive Weighting 


\subsection{Analisis Pencarian Solusi dengan Metode Metode Profile Matching}

Langkah-langkah dalam penyelesaian perhitungan dengan menggunakan metode Profile Matching [10]:

a. Aspek-aspek penilaian.

b. Pemetaan GAP kompetisi.

c. Pembobotan GAP kompetisi.

d. Perhitungan dan pengelompokan Core Factor dan Secondary Factor

1) Perhitungan core factor menggunakan rumus di bawah ini:

$$
\mathrm{NCF}=\boldsymbol{\Sigma} \mathrm{NC}(\text { aspek }) / \Sigma \mathrm{IC} \text {. }
$$

yang mana:

$\mathrm{NCF}=$ Nilai rata-rata core factor .

$\Sigma \mathrm{NC}($ aspek $)=$ Jumlah total nilai core factor .

$\Sigma \mathrm{IC}=$ Jumlah item core factor .

2) Perhitungan secondary factor bisa ditunjukkan dengan rumus berikut:

$\mathrm{NSF}=\boldsymbol{\Sigma} \mathrm{NS}$ (aspek) $/ \boldsymbol{\Sigma} \mathrm{IS}$

yang mana:

$\mathrm{NSF}=$ Nilai rata-rata secondary factor.

$\Sigma \mathrm{NS}($ aspek $)=$ jumlah total nilai secondary factor.

$\Sigma \mathrm{IS}=$ Jumlah item secondary factor .

e. Perhitungan nilai total

Rumus perhitungan nilai total adalah sebagai berikut:

$$
(\mathrm{x}) \% \mathrm{NCF}(\text { aspek })+(\mathrm{x}) \% \mathrm{NSF}(\text { aspek })=\mathrm{N}(\text { aspek }) \text {. }
$$

yang mana:

$\mathrm{NCF}($ aspek $)=$ nilai rata-rata core factor $($ aspek).

$\mathrm{NSF}($ aspek $)=$ nilai rata-rata secondary factor (aspek).

$\mathrm{N}($ aspek $)=$ nilai aspek (aspek).

$(\mathrm{x}) \%=$ nilai persen yang di-input-kan.

f. Perhitungan penentuan ranking mengacu pada hasil perhitungan

Rumus perhitungan penentuan ranking adalah sebagai berikut:

$\Sigma(\mathrm{x}) \% \mathrm{Nk}$

yang mana:

$\mathrm{Nk}=$ nilai kriteria.

$(\mathrm{x}) \%=$ nilai persen yang di-input-kan.

Tabel 7 di bawah ini berisi bobot nilai gap sesuai ketentuan dalam metode Profile Matching.

Tabel 7. Bobot Nilai Gap [7]

\begin{tabular}{ccl}
\hline \hline Selisih Gap & Bobot Nilai & \multicolumn{1}{c}{ Keterangan } \\
\hline 0 & 5,0 & Kriteria sesuai dengan yang dibutuhkan \\
1 & 4,5 & Kriteria kelebihan 1 tingkat/level \\
-1 & 4,0 & Kriteria kurang 1 tingkat/level \\
2 & 3,5 & Kriteria kelebihan 2 tingkat/level \\
-2 & 3,0 & Kriteria kurang 2 tingkat/level \\
3 & 2,5 & Kriteria kelebihan 3 tingkat/level \\
-3 & 2,0 & Kriteria kurang 3 tingkat/level \\
4 & 1,5 & Kriteria kelebihan 4 tingkat/level \\
-4 & 1,0 & Kriteria kurang 4 tingkat/level
\end{tabular}

Dengan acuan data pada Tabel 1 sampai Tabel 3 tentang kriteria dan bobot nilai untuk kriteria, serta acuan data pada tabel 4 yang berisi data calon penerima dana BSM, maka penyelesaian permasalahan pendistribusian dana BSM dengan metode Profile Matching terdiri dari langkahlangkah di bawah ini:

a. Menghitung Gap

Hasil penilaian angket (kolom K1 sampai kolom K4) pada Tabel 4 disalin ke dalam empat baris pertama pada Tabel 8, kemudian nilai-nilai itu dikurangkan dengan nilai acuan untuk memperoleh selisih gap di empat baris yang terakhir pada Tabel 8 ini pula. 
Tabel 8. Selisih Gap

\begin{tabular}{|c|c|c|c|c|}
\hline Nama Siswa & K1 & K2 & K3 & $\overline{\mathrm{K} 4}$ \\
\hline Bambang Suhartoyo & 4 & 4 & 1 & 0 \\
\hline Melati Anggraini & 4 & 4 & 0 & 0 \\
\hline Agustin Neni & 2 & 4 & 3 & 3 \\
\hline Pongki Pramudia & 10 & 8 & 2 & 2 \\
\hline Moh. Saiful & 4 & 4 & 1 & 1 \\
\hline Andik Arafik & 2 & 4 & 2 & 2 \\
\hline Nilai acuan & 6 & 8 & 3 & 2 \\
\hline \multicolumn{5}{|c|}{ Hasil Selisih } \\
\hline Bambang Suhartoyo & -2 & -4 & -2 & -2 \\
\hline Melati Anggraini & -2 & -4 & -3 & -2 \\
\hline Agustin Neni & -4 & -4 & 0 & 2 \\
\hline Pongki Pramudia & 4 & 0 & -1 & 0 \\
\hline Moh. Saiful & -2 & -4 & -2 & -1 \\
\hline Andik Arafik & -4 & -4 & -1 & 0 \\
\hline
\end{tabular}

b. Pembobotan

Nilai selisih gap di empat baris terakhir pada Tabel 8 kemudian dibandingkan dengan selisih gap pada Tabel 7 untuk memberi bobot nilai kepada tiap-tiap alternatif yang hasilnya tertulis pada Tabel 9.

Tabel 9. Hasil Pembobotan

\begin{tabular}{lrrrr}
\hline \hline \multicolumn{1}{c}{ Nama Siswa } & K1 & \multicolumn{1}{c}{ K2 } & \multicolumn{1}{c}{ K3 } & K4 \\
\hline Bambang Suhartoyo & 3.0 & 1.0 & 3.0 & 3.0 \\
Melati Anggraini & 3.0 & 1.0 & 2.0 & 3.0 \\
Agustin Neni & 1.0 & 1.0 & 5.0 & 3.5 \\
Pongki Pramudia & 1.5 & 5.0 & 4.0 & 5.0 \\
Moh. Saiful & 3.0 & 1.0 & 3.0 & 4.0 \\
Andik Arafik & 1.0 & 1.0 & 4.0 & 5.0
\end{tabular}

c. Perhitungan core factor dan secondary factor

Kriteria-kriteria pada Tabel 1 dapat dikelompokkan menjadi kelompok core factor dan kelompok secondary factor. Kelompok core factor merupakan faktor utama dalam penilaian, yaitu meliputi penghasilan orangtua/wali dan keadaan bangunan rumah orangtua/wali. Kelompok secondary factor merupakan faktor pendukung dari core factor, yaitu meliputi jumlah saudara siswa dan jumlah anak yang masih menjadi tanggungan orangtua.

Berdasarkan hasil pembobotan pada Tabel 9 dapat dilakukan proses perhitungan core factor dan perhitungan secondary factor untuk setiap siswa sebagai berikut:

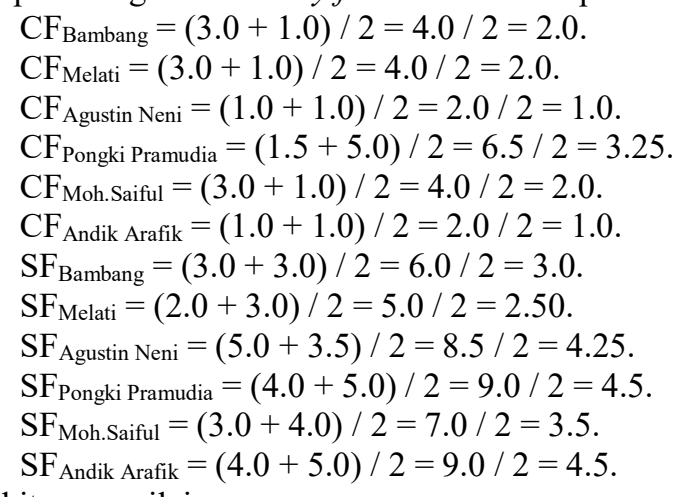

d. Perhitungan nilai

Berdasarkan Tabel 1 kelompok core factor (meliputi penghasilan orangtua/wali dan keadaan bangunan rumah orangtua/wali) memiliki persentase nilai 35\%, dan kelompok secondary factor (meliputi jumlah saudara siswa dan Jumlah anak yang masih menjadi tanggungan orangtua) memiliki pensentase nilai $15 \%$. 
Kemudian hasil perhitungan core factor dan secondary factor dari langkah (c) dikalikan dengan persentase nilai yang telah ditetapkan pada Tabel 1, sehingga menghasilkan perhitungan di bawah ini:

$$
\begin{aligned}
& N_{\text {Bambang }}=(35 / 100 * 2.0)+(15 / 100 * 3.0)=0.7+0.45=1.15 \\
& N_{\text {Melati }}=(35 / 100 * 2.0)+(15 / 100 * 2.5)=0.7+0.375=1.075 \\
& N_{\text {Agustin }}=(35 / 100 * 1.0)+(15 / 100 * 4.25)=0.35+0.6375=0.9875 \\
& N_{\text {Pongki }}=(35 / 100 * 3.25)+(15 / 100 * 4.5)=1.1375+0.675=1.8125 \\
& N_{\text {Saiful }}=(35 / 100 * 2.0)+(15 / 100 * 3.5)=0.7+0.525=1.225 \\
& N_{\text {Andik }}=(35 / 100 * 1.0)+(15 / 100 * 4.5)=0.35+0.675=1.025
\end{aligned}
$$

e. Perankingan

Hasil perhitungan nilai pada langkah (d) dapat diurutkan descending untuk membentuk ranking peluang penerima BSM dengan hasil seperti yang tertulis pada Tabel 10 .

\begin{tabular}{|c|c|c|c|}
\hline Nama Siswa & KPS/SKM & Prioritas & Solusi \\
\hline Ninik Setyorini & $\mathrm{Y}$ & $\sim$ & Urutan 1 \\
\hline Indah Astutik & $\mathrm{Y}$ & $\sim$ & Urutan 1 \\
\hline Tomy Setyawan & $\mathrm{Y}$ & $\sim$ & Urutan 1 \\
\hline Setiawan & $\mathrm{Y}$ & $\sim$ & Urutan 1 \\
\hline Pongki Pramudia & $\mathrm{T}$ & 1.8125 & Urutan 2 \\
\hline Moh. Saiful & $\mathrm{T}$ & 1.225 & Urutan 3 \\
\hline Bambang Suhartoyo & $\mathrm{T}$ & 1.15 & Urutan 4 \\
\hline Melati Anggraini & $\mathrm{T}$ & 1.075 & Urutan 5 \\
\hline Andik Arafik & $\mathrm{T}$ & 1.025 & Urutan 6 \\
\hline Agustin Neni & $\mathrm{T}$ & 0.9875 & Urutan 7 \\
\hline
\end{tabular}

Tabel 10. Perankingan Nilai

\begin{aligned} \hline \hline Nilai Priority & \multicolumn{1}{c}{ Nama Siswa } \\ \hline 1.8125 & Pongki Pramudia \\ 1.225 & Moh. Saiful \\ 1.15 & Bambang Suhartoyo \\ 1.075 & Melati Anggraini \\ 1.025 & Andik Arafik \\ 0.9875 & Agustin Neni \end{aligned}

Solusi lengkap dengan metode Profile Matching dapat disusun menjadi suatu informasi penyaluran dana BSM seperti yang ditulis pada Tabel 11.

Tabel 11. Solusi dari Metode Profile Matching

\section{SIMPULAN}

adalah:

Kesimpulan Peneliti setelah membuat perbandingan hitungan dari masing-masing metode

a. Dua buah metode yang diperbandingkan dalam penelitian ini sama-sama dapat dipakai di dalam sistem pendukung keputusan untuk mencari solusi atas permasalahan pendistribusian dana BSM, tergantung kepada karakteristik nilai pada keluaran yang diinginkan.

b. Jika diinginkan suatu keluaran berupa persentase nilai prioritas, maka pencarian solusi lebih tepat metode Simple Additive Weighting. Jika diinginkan suatu keluaran berupa nilai nilai peluang/probabilitas, maka metode Profile Matching lebih tepat dipakai untuk pencarian solusi.

c. Mengenai metode mana yang terbaik untuk dipakai dalam pemecahan permasalahan pendistribusian dana BSM sangat dipengaruhi oleh jumlah data yang diproses dan apa macam permasalahan yang akan diselesaikan serta karakteristik dari nilai keluaran yang diinginkan oleh pengguna. 


\section{SARAN}

Pada kesempatan ini peneliti dapat menyampaikan saran kepada para peneliti lain yang berminat untuk meneruskan penelitian saat ini adalah mengenai: Pada penelitian ini baru dapat dibahas mengenai karakteristik data pada nilai keluaran yang dipakai untuk menentukan pemilihan suatu metode yang cocok dalam penyelesaian permasalahan. Untuk itu diharapkan para peneliti lain dapat menemukan suatu metode yang terbaik untuk permasalahan ini yang ditinjau dari sisi karakteristik data secara total.

\section{DAFTAR PUSTAKA}

[1] Pengertian BSM [Online] // digilib.unila.ac.id. -Tanggal diakses 23 Mei 2018.

[2] BPS konsep kemiskinan [Online] // bpsjatim. -Tanggal diakses 23 Mei 2018.

[3] TNP2K, 2015, Penetapan Solusi Masalah Kepesertaan dan Pemutakhiran Data Penerima KPS, Jakarta.

[4] Turban, Efraim; Aronson, Jay E.; Liang, Ting-Peng, 2005, Decision Support Systems and Intelligent Systems-7th Ed Jilid 1, Andi Offset, Yogyakarta.

[5] Wahid, Fathul, 2005, Kamus Istilah Teknologi Informasi, Andi Offset, Yogyakarta.

[6] Kusrini, 2007, Konsep dan Sistem Pendukung Keputusan, Andi Offset, Yogyakarta.

[7] Sari, Bety Wulan, 2015, Perbandingan Metode Profile Matching dan Simple Additive Weighting pada Penentuan Jurusan Siswa Kelas X SMA N 2 Ngaglik, Jurnal Ilmiah DASI Vol 16 No 1.

[8] Maulany, Gerzon J, 2015, Sistem Pendukung Keputusan untuk Menentukan Penilaian Good Governance pada Suatu Kabupaten menggunakan Algoritma Simple Additive Weighting (SAW), Jurnal Ilmiah Mustek Anim Ha Vol. 4 No. 1.

[9] Sidik, Rohman, 2014, Sistem Pendukung Keputusan dalam Menentukan Kelayakan Lokasi untuk Membangun Tower Pemancar Sinyal menggunakan Metode Simple Additive Weighting (SAW), Pelita Informatika Budi Darma, Volume : VI, Nomor: 1.

[10] Ichsan, T.M. Syahru, 2015, Sistem Pendukung Keputusan Pemilihan Penerima Beasiswa Mahasiswa Kurang Mampu pada STMIK Budidarma Medan Menerapkan Metode Profile Matching, Pelita Informatika Budi Darma, Volume: V, Nomor: 1. 